University of Nebraska - Lincoln

DigitalCommons@University of Nebraska - Lincoln

1985

Protein Supplementation of Ammoniated Roughages. II. Wheat

Straw Supplemented with Alfalfa, Blood Meal or Soybean Meal

Fed to Wintering Steers

\author{
M. L. Nelson \\ University of Nebraska, Panhandle Research and Extension Center \\ Ivan G. Rush \\ University of Nebraska-Lincoln, irush1@unl.edu \\ T. J. Klopfenstein \\ University of Nebraska-Lincoln, tklopfenstein1@unl.edu
}

Follow this and additional works at: https://digitalcommons.unl.edu/panhandleresext

Part of the Agriculture Commons

Nelson, M. L.; Rush, Ivan G.; and Klopfenstein, T. J., "Protein Supplementation of Ammoniated Roughages. II. Wheat Straw Supplemented with Alfalfa, Blood Meal or Soybean Meal Fed to Wintering Steers" (1985). Panhandle Research and Extension Center. 21.

https://digitalcommons.unl.edu/panhandleresext/21

This Article is brought to you for free and open access by the Agricultural Research Division of IANR at DigitalCommons@University of Nebraska - Lincoln. It has been accepted for inclusion in Panhandle Research and Extension Center by an authorized administrator of DigitalCommons@University of Nebraska - Lincoln. 


\title{
PROTEIN SUPPLEMENTATION OF AMMONIATED ROUGHAGES. II. WHEAT STRAW SUPPLEMENTED WITH ALFALFA, BLOOD MEAL OR SOYBEAN MEAL FED TO WINTERING STEERS ${ }^{1}$
}

\author{
M. L. Nelson, I. G. Rush ${ }^{2}$ and T. J. Klopfenstein \\ University of Nebraska ${ }^{3}$, Lincoln $68583-0908$
}

\begin{abstract}
Two winter steer growth trials were conducted to investigate responses of steer calves to ammoniation of wheat straw, level of alfalfa haylage ( 50 or $66.7 \%$ of diet) and source of supplemental protein, soybean meal (SBM), blood meal (BM), or a blood meal-urea mixture (BM-U). In trial 1, the main effect of ammoniation significantly increased average daily gain (ADG) from .15 to .24 $\mathrm{kg} / \mathrm{d}$, dry matter intake (DMI) from 4.86 to $5.29 \mathrm{~kg} / \mathrm{d}$ and gain/feed from .029 to .044 . The higher level of alfalfa haylage significantly increased DMI from 4.78 to $5.36 \mathrm{~kg} / \mathrm{d}$. Gain during a subsequent grazing period was unaffected by winter diet. In trial 2 , the main effect of ammoniation significantly increased ADG from .26 to $.38 \mathrm{~kg} / \mathrm{d}$ and DMI from 4.28 to $4.78 \mathrm{~kg} / \mathrm{d}$. The main effect of supplement showed that ADG was significantly greater for the SBM-fed steers than for either the BM- or BM-U-fed steers. A significant ammonia $X$ supplement interaction was noted for gain/ feed; the response due to protein supplement differed, depending on whether or not the straw was ammoniated.
\end{abstract}

(Key Words: Ammoniated Feeds, Wheat Straw, Protein Supplements, Steers.)

Introduction

Wheat straw, due to its low energy density, may not support maintenance in weaned calves. However, if its digestibility and $\mathrm{N}$ content is improved by ammoniation, it might be utilized in combination with other ingredients for wintering calves returning to pasture the following year.

Positive associative effects have been reported for alfalfa inclusion in diets of $\mathrm{NaOH}$ - or $\mathrm{NH}_{3}$-treated corn cobs or wheat straw (Maeng et., 1970; Paterson et al., 1981; Cook, 1981; Paterson et al., 1982). Therefore, alfalfa may be a good complementary feedstuff to be fed with ammoniated wheat straw.

Blood meal protein is essentially indigestible in the rumen (Stock, 1982), whereas soybean meal protein is 60 to $80 \%$ degraded in the rumen (Hume, 1974; Kropp et al., $1976 \mathrm{Mer}-$ chen et al., 1979. Peterson 1981; Zinn et al., 1981). Additionally, a 50:50 mixture of blood meal and urea (on a protein basis) has been

\footnotetext{
${ }^{1}$ Published with the approval of the Director as Paper No. 7388 Journal Ser., Nebraska Agr. Exp. Sta.

${ }^{2}$ Panhandle Station, Scottsbluff, NE 69361.

${ }^{3}$ Dept. of Anim. Sci.

Received February 3, 1984.

Accepted January 29, 1985.
}

shown to support rates of gain approximately equal to those of soybean meal when supplementing a corn silage-corn cob diet fed to growing steers (Stock et al., 1981).

Ammoniation enhances the $\mathrm{N}$ content of feedstuffs, with the largest retained fraction as free ammonia (Solaiman et al., 1978; Abidin and Kempton, 1981). But $\mathrm{N}$ is also present in bound forms (Kowalczyk, 1977) that may (Millar, 1944; McCall and Graham, 1953; Horton, 1979; Horton and Steacy, 1979) or may not (Hershberger et al., 1959; Garrett et al., 1974; Oji et al., 1977 Borhami and Johnsen, 1981) be utilized. With high dry matter feedstuffs, however, the ammonia retained after ammoniation will be less than low dry matter feedstuffs due to the dissociation constant of $\mathrm{NH}_{4} \mathrm{OH}$ and the pka of ammonia, allowing sizable volatile ammonia losses. The major objectives of the current studies were to investigate the responses in winter performance of steer calves due to ammoniation of wheat straw, level of alfalfa haylage and source of supplemental protein (soybean meal, blood meal or a blood meal urea mixture).

\section{Experimental Procedure}

Trial 1. Ninety-six Angus steers $(261 \mathrm{~kg})$ were randomly allotted to 12 pens of eight steers with three pens/treatment. A $2 \times 2$ 245

JOURNAL OF ANIMAL SCIENCE, Vol. 61, No. 1, 1985 
TABLE 1. DIET COMPOSITION (TRIAL 1)

\begin{tabular}{|c|c|c|c|c|}
\hline \multirow[b]{2}{*}{ Ingredient } & \multicolumn{2}{|c|}{ High haylage } & \multicolumn{2}{|c|}{ Low haylage } \\
\hline & $\begin{array}{l}\text { Control } \\
\text { straw }\end{array}$ & $\begin{array}{l}\text { Ammoniated } \\
\text { straw }\end{array}$ & $\begin{array}{l}\text { Control } \\
\text { straw }\end{array}$ & $\begin{array}{l}\text { Ammoniated } \\
\text { straw }\end{array}$ \\
\hline & \multicolumn{4}{|c|}{ \% DM basis } \\
\hline $\begin{array}{l}\text { Alfalfa haylage } \\
\text { Wheat straw }\end{array}$ & $\begin{array}{l}66.7 \\
31.6\end{array}$ & 66.7 & $\begin{array}{l}50 \\
47.4\end{array}$ & 50 \\
\hline Ammoniated straw & & 31.6 & & 47.4 \\
\hline Supplement & $1.7^{\mathbf{a}}$ & $1.7^{\mathrm{a}}$ & $2.6^{b}$ & $2.6^{\mathrm{c}}$ \\
\hline
\end{tabular}

${ }^{a}$ Supplement 1 (see table 2).

${ }^{\text {b }}$ Supplement 2 (see table 2).

Supplement 3 (see table 2).

factorial arrangement of dietary treatments was utilized. The main effects investigated were ammoniation of wheat straw (0 or $4 \mathrm{~g} / 100 \mathrm{~g}$ dry matter) and level of alfalfa haylage dry matter in the diet (50 or $66.7 \%$ ). Supplements were fed as a fixed proportion of the straw component of the diet (tables 1 and 2) and were formulated so that the diet contained .5\% $\mathrm{Ca}, .3 \% \mathrm{P}, .25 \%$ salt, $.05 \%$ trace minerals and 2,200 IU vitamin A per kg. Supplements 2 and 3 were formulated assuming the equal protein contribution from blood meal and corn gluten meal would be utilized at twice the efficiency of soybean meal (Stock et al., 1981). Urea was included in the supplement fed in conjunction with the untreated straw-low haylage level in an amount to provide the same quantity of $\mathrm{N}$ as the blood meal-corn gluten meal mixture. Thus, all diets contained at least $11.5 \%$ crude protein equivalent. The 150-d wintering period from December 17, 1980 to May 15, 1981 was followed by a 130-d grazing period (May 15, 1981 to September 21, 1981) where steers grazed a common, predominantly crested wheat grass, pasture. Initial and final steer weights for the wintering period, were the average of two consecutive day weighings. Steers were fed alfalfa haylage before the initial weight was

TABLE 2. SUPPLEMENT COMPOSITION (TRIAL 1)

\begin{tabular}{lccr}
\hline & & Supplement number \\
\cline { 2 - 4 } Ingredient & 1 & 2 & 3 \\
\hline & & \% DM basis & \\
Corn (IFN 4-02-861) & 64.75 & 10.91 & 24.96 \\
Blood meala (IFN 5-00-380) & & 19.43 & 18.60 \\
Corn gluten meal (IFN 5-02-900) & & 25.41 & 24.33 \\
Urea (IFN 5-05-070) & 17.68 & 12.14 & 20.42 \\
Dicalcium phosphate (IFN 6-01-080) & 14.29 & 20.42 & 9.51 \\
Salt (IFN 6-20-226) & 2.86 & 9.51 & 1.90 \\
Trace mineralsb & .42 & 1.90 & .28 \\
Vitaminsc & 6.48 & .28 & 34.12 \\
Calculated CP & 9.26 & 68.24 & 34.65 \\
Actual CP & & 74.66 & \\
\hline
\end{tabular}

\footnotetext{
${ }^{\mathbf{a}}$ Ring dried.

${ }_{10} \% \mathrm{Mn}, 10 \% \mathrm{Fe}, 10 \% \mathrm{Zn}, 1 \% \mathrm{Cu}, .3 \% \mathrm{I}, .1 \% \mathrm{Co}$.

$c_{30,000} \mathrm{IU}$ vitamin $\mathrm{A}, 8,000 \mathrm{IU}$ vitamin $\mathrm{D}$ and $10 \mathrm{IU}$ vitamin $\mathrm{E}$ per $\mathrm{g}$.
} 
recorded, and for $4 \mathrm{~d}$ before the final weight, to reduce fill differences.

Data were analyzed by analysis of variance (Snedecor and Cochran, 1967) for a factorial in a completely random design.

Trial 2. Ninety-six Angus steers $(230 \mathrm{~kg}$ ) were randomly allotted to 12 pens of eight steers with two pens/treatment. A $2 \times 3$ factorial arrangement of dietary treatments was utilized. The main effects investigated were ammoniation of wheat straw ( 0 or $3 \mathrm{~g} \mathrm{NH}_{3} / 100$ $g$ dry matter) and source of supplemental protein (soybean meal, blood meal or a blood meal-urea mixture). Supplements (table 3) were formulated assuming that blood meal was utilized at twice the efficiency of soybean meal (Stock et al., 1981), with or without urea, providing an equal amount of crude-proteinequivalent. Diets (on a dry matter basis) were $45 \%$ corn silage, $45 \%$ wheat straw and $10 \%$ supplement and were formulated to contain $.31 \% \mathrm{Ca}, .28 \% \mathrm{P}, .15 \%$ salt, $.05 \%$ trace minerals, $2,200 \mathrm{IU}$ vitamin $\mathrm{A}$ per $\mathrm{kg}$ and at least $10.1 \%$ crude protein, with exception of the blood meal supplement fed in conjunction with the untreated straw. The 110-d wintering period was from December 18, 1981 to April 7, 1982. Initial and final steer weights were the average of weights recorded on two consecutive days. Steers were fed $75 \%$ alfalfa haylage, $25 \%$ corn silage before the initial weight, and for $4 \mathrm{~d}$ before the final weight, to reduce fill differ- ences. Data were analyzed by analysis of variance for a factorial experiment in a completely random design (Snedecor and Cochran, 1967). Means within the main effect of supplemental protein were tested using the Least Significant Difference test, protected by a significant F-test (Snedecor and Cochran, 1967).

Straw Ammoniation and Feeding Regimen. The wheat straw was baled in $27-\mathrm{kg}$, square, wire-tied bales. Eight-hundred-fifty bales were stacked and covered with plastic. Anhydrous ammonia was injected at a single point into the straw stack in early October, in both years, using a pipe coupled to an anhydrous ammonia nurse tank with an anhydrous regulator. The stack remained sealed until initiation of feeding in mid-December, at which time the stack was opened and aeration was allowed. Core samples of 20 individual bales were collected as feeding progressed; samples were composited for subsequent analysis.

Steers were pen fed, once daily, allowing ad libitum intake of the complete diet. Straw was fed unground, behind slanted bars attached to the feed bunk, and was not mixed with the other diet ingredients. Therefore, straw consumption limited intake of the complete diet.

Dry matter (DM), crude protein (CP), in vitro dry matter disappearance (IVDMD), neutral detergent fiber (NDF), acid detergent fiber (ADF), acid detergent lignin (ADL),

TABLE 3. SUPPLEMENT COMPOSITION (TRIAL 3)

\begin{tabular}{|c|c|c|c|}
\hline \multirow[b]{2}{*}{ Ingredient } & \multicolumn{3}{|c|}{ Supplement } \\
\hline & $\begin{array}{l}\text { Soybean } \\
\text { meal }\end{array}$ & $\begin{array}{l}\text { Blood } \\
\text { meal }\end{array}$ & $\begin{array}{l}\text { Blood } \\
\text { meal } \\
\text { urea }\end{array}$ \\
\hline & & \% DM basis & \\
\hline Soybean meal (IFN 5-04-604) & 90.73 & & \\
\hline Blood mealb (IFN 5-00-380) & & 18.71 & 19.82 \\
\hline Urea (IFN 5-05-070) & & & 8.36 \\
\hline Corn (IFN 4-02-861) & 2.75 & 72.60 & 62.96 \\
\hline Dicalcium phosphate (IFN 6-01-080) & 4.45 & 6.62 & 6.78 \\
\hline Trace mineral premix & .50 & .50 & .50 \\
\hline Salt (IFN 6-20-226) & 1.50 & 1.50 & 1.50 \\
\hline Vitamin premix $c$ & .07 & .07 & .07 \\
\hline Calculated CP & 47.0 & 23.5 & 47.0 \\
\hline Actual CP & 41.6 & 20.0 & 53.3 \\
\hline
\end{tabular}

\footnotetext{
${ }^{a}$ Diets were $45 \%$ corn silage, $45 \%$ wheat straw and $10 \%$ supplement.

${ }^{b}$ Ring dried.

See table 1 .
} 
TABLE 4. CHEMICAL ANALYSIS OF WHEAT STRAW

\begin{tabular}{|c|c|c|c|c|}
\hline \multirow[b]{2}{*}{ Item $^{a}$} & \multicolumn{2}{|c|}{ Trial 1} & \multicolumn{2}{|c|}{ Trial 2} \\
\hline & Wheat straw & $\begin{array}{l}\text { Ammoniated } \\
\text { straw }\end{array}$ & Wheat straw & $\begin{array}{l}\text { Ammoniated } \\
\text { straw }\end{array}$ \\
\hline & & & & \\
\hline DM & 92.5 & 91.9 & 94.3 & 92.3 \\
\hline IVDMD & 50.0 & 56.2 & 44.5 & 48.7 \\
\hline NDF & 82.2 & 80.6 & 88.6 & 84.2 \\
\hline ADF & 53.5 & 54.6 & 60.8 & 59.9 \\
\hline ADL & 5.9 & 5.9 & 12.5 & 10.1 \\
\hline Total N & .52 & 1.34 & .41 & .90 \\
\hline $\mathrm{NH}_{3}-\mathrm{N}$ & .00 & .35 & .00 & .43 \\
\hline $\mathrm{NDF}-\mathrm{N}$ & .18 & .21 & .14 & .22 \\
\hline ADF-N & .17 & .18 & .07 & .18 \\
\hline $\mathrm{N}$-remainder & .35 & .77 & .27 & .26 \\
\hline
\end{tabular}

${ }^{a} \mathrm{DM}=\mathrm{dry}$ matter, IVDMD=in vitro dry matter disappearance, NDF=neutral detergent fiber, ADF=acid detergent fiber, $\mathrm{ADL}=$ acid detergent lignin, $\mathrm{n}=$ nitrogen, $\mathrm{NH}_{3}=$ ammonia, $\mathrm{N}-$ remainder=total $\mathrm{N}-\left(\mathrm{NH}_{3}-\mathrm{N}+\mathrm{NDF}-\mathrm{N}+\mathrm{ADF}\right.$ N).

ammonia $\left(\mathrm{NH}_{3}\right)$, and in vitro rate of digestion were determined as described by Nelson et al. (1984a).

\section{Results}

Trial 1. Ammoniation of wheat straw (table 4) increased the IVDMD by 6.2 percentage units (50.0 vs $56.2 \%$ ) and $C P$ content of the aerated straw by 5 percentage units ( 3.3 vs $8.4 \%$ ), decreased NDF slightly and did not affect ADF or ADL. The $\mathrm{N}$ fractions (table 4) show that while some enrichment in cell wall $\mathrm{N}$ (NDF-N and ADF-N) occurred, the fraction showing the largest increase was in ammo- nia- $\mathrm{N}\left(\mathrm{NH}_{3}-\mathrm{N}\right)$. Ammoniation did not increase in vitro rate of straw ADF digestion or decrease lag phase, but it did increase $(P=.08)$ the extent of ADF digestion (table 5). The alfalfa haylage contained $22.4 \%$ CP and $56.6 \%$ IVDMD.

Winter performance of the steers is shown in table 6. The main effect of ammoniation significantly increased average daily gain (ADG) from .15 to $.24 \mathrm{~kg} / \mathrm{d}$, dry matter intake (DMI) from 4.86 to $5.29 \mathrm{~kg} / \mathrm{d}$ and gain $/$ feed from .029 to .044 . The main effect of alfalfa haylage level significantly increased DMI from 4.78 to 5.36 $\mathrm{kg} / \mathrm{d}$, without improving ADG or gain $/ \mathrm{feed}$. The higher level of alfalfa haylage appeared to

TABLE 5. IN VITRO ACID DETERGENT FIBER RATE MEASUREMENTS OF WHEAT STRAW

\begin{tabular}{|c|c|c|c|c|c|c|c|c|}
\hline \multirow[b]{3}{*}{ Item } & \multicolumn{4}{|c|}{ Trial 1} & \multicolumn{4}{|c|}{ Trial 2} \\
\hline & \multicolumn{2}{|c|}{$\begin{array}{l}\text { Ammonia, } \\
\text { g/100 g DM }\end{array}$} & \multirow[b]{2}{*}{$\mathrm{SE}$} & \multirow[b]{2}{*}{$\mathrm{P}^{\mathbf{a}}$} & \multicolumn{2}{|c|}{$\begin{array}{l}\text { Ammonia, } \\
\text { g/100 g DM }\end{array}$} & \multirow[b]{2}{*}{ SE } & \multirow[b]{2}{*}{$\mathbf{p}^{\mathbf{a}}$} \\
\hline & 0 & 4 & & & 0 & 3 & & \\
\hline $\begin{array}{l}\text { Rate of digestion, } \\
\% / \mathrm{h}\end{array}$ & 3.23 & 3.92 & .16 & .20 & 4.98 & 6.25 & .11 & .08 \\
\hline $\begin{array}{l}\text { Extent of digestion, } \\
\text { g ADF remaining at } \\
96 \mathrm{~h} / 100 \mathrm{~g} \mathrm{ADF}\end{array}$ & 41.79 & 30.02 & .97 & .08 & 41.49 & 42.84 & 3.75 & .74 \\
\hline Lag phase, $\mathrm{h}$ & 11.58 & 7.16 & .16 & .03 & 11.45 & 15.16 & .34 & .08 \\
\hline
\end{tabular}

${ }^{\text {a }}$ Probability for ammonia. 
TABLE 6. PERFORMANCE OF STEERS FED WHEAT STRAW-ALFALFA HAYLAGE (TRIAL 1)

\begin{tabular}{|c|c|c|c|c|c|}
\hline \multirow[b]{3}{*}{ Item } & \multicolumn{2}{|c|}{ Wheat straw } & \multicolumn{2}{|c|}{ Ammoniated straw } & \multirow[b]{3}{*}{ SE } \\
\hline & \multicolumn{2}{|c|}{ Haylage level, \% } & \multicolumn{2}{|c|}{ Haylage level, $\%$} & \\
\hline & 50 & 66.7 & 50 & 66.7 & \\
\hline Winter $A D G^{a}, \mathrm{~kg} / \mathrm{d}$ & .12 & .17 & .23 & .24 & .015 \\
\hline Feed intake $\mathrm{e}^{\mathrm{ab}}, \mathrm{kg} / \mathrm{d}$ & 4.60 & 5.12 & 4.96 & 5.61 & .121 \\
\hline Gain/feed ${ }^{a}$ & .026 & .032 & .046 & .043 & .003 \\
\hline Grazing ADG, kg/d & .74 & .72 & .69 & .68 & .029 \\
\hline
\end{tabular}

${ }^{a}$ Increase due to main effect of ammoniation $(P<.01)$.

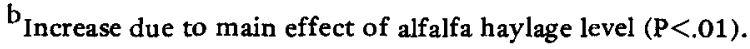

improve winter gain and gain/feed with the control straw, but not with the ammoniated straw. Gain during the grazing period, while slightly less for the calves wintered on ammoniated straw, was not significantly affected by wintering treatment. Thus, calves wintered while fed ammoniated straw were heavier at the end of both the wintering and the grazing period than calves wintered while fed the control straw.

Trial 2. Ammoniation of the straw used in trial 2, which was weathered, resulted in only small increases in IVDMD (4.2 percentage units) and $\mathrm{CP}$ ( 3.0 percentage units) content, while NDF decreased by 4.4 percentage units (table 4). Additionally, the weathered straw appeared to contain more NDF, ADF, ADL and less IVDMD than the straw used in Trial 1 and the increase was less than previously observed (Solaiman et al., 1978; Faulkner, 1980). The N fractions (table 4), $\mathrm{NH}_{3}-\mathrm{N}, \mathrm{NDF}-\mathrm{N}$ and ADF-N, were enriched to a greater extent, even though the total $\mathbf{N}$ enrichment was less, in the weathered straw (Trial 2) than in the unweathered straw (Trial 1). Inexplicably, the uncharacterized $N$ ( $N$ remainder), which might be in the solubilized hemicellulose, less tightly bound in the cell wall than NDF-N and ADF-N or in forms not measured by the indophenol procedure, was not increased by ammoniation of the weathered straw in Trial 2 . In vitro rate of ADF digestion (table 5) was increased $(P=.08)$ and lag phase decreased $(\mathrm{P}=.08)$ without affecting the extent of ADF digestion by ammoniation. The corn silage fed contained 8.4\% CP and $77.8 \%$ IVDMD.

Performance of steers in Trial 2 is shown in table 7. Ammoniation increased $(\mathrm{P}<.05)$ ADG from .26 to $.38 \mathrm{~kg} / \mathrm{d}$ and DMI from 4.28 to $4.78 \mathrm{~kg} / \mathrm{d}$. The main effect of protein supple- ment showed that ADG was greater $(\mathbf{P}<.05)$ for the soybean meal-fed steers $(.40 \mathrm{~kg} / \mathrm{d})$ than for either the blood meal- $(.25 \mathrm{~kg} / \mathrm{d})$ or the blood meal-urea- $(.31 \mathrm{~kg} / \mathrm{d})$ fed steers. Dry matter intake, while slightly lower for the blood mealand blood meal-urea-fed steers than the soybean meal-fed steers, was not affected by protein supplement. A significant ammonia $x$ supplement interaction was detected for gain/feed (table 7), wherein soybean meal equaled blood meal-urea and both appeared greater than blood meal with the untreated straw-fed steers. However, with the ammoniated straw the soybean meal-fed steers appeared to have a greater gain/feed than either the blood meal- or blood meal-urea-fed steers.

\section{Discussion}

Addition of alfalfa to $\mathrm{NaOH}$-treated corncobs or wheat straw has resulted in positive associative effects on DM digestibility and daily gain (Maeng et al., 1970; Paterson et al., 1982). Similar responses have been noted by $50 \%$ alfalfa addition to $\mathrm{NH}_{3}$-treated or untreated corncobs in ADG of steers (Paterson et al., 1981). However, no positive associative effect on DM digestibility was noted from alfalfa

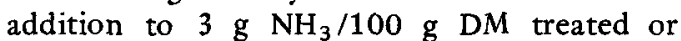
untreated cornstalks (Paterson et al., 1981).

Explanations for these positive associative effects include slowed rate of particulate passage and provision of additional minerals; especially $\mathrm{K}, \mathrm{Ca}$ and $\mathrm{Mg}$ (Paterson et al., 1982). However, an additional explanation is an increase in microbial cell yields when small quantities of amino acids are present, as was shown by Maeng and Baldwin (1976) in vitro, with an ammonia-containing media. This is supported by data of Cook (1981), who noted 
TABLE 7. PERFORMANCE OF STEERS FED WHEAT STRAW-CORN SILAGE (TRIAL 2)

\begin{tabular}{|c|c|c|c|c|c|c|c|}
\hline \multirow[b]{3}{*}{ Item } & \multicolumn{3}{|c|}{ Wheat straw } & \multicolumn{3}{|c|}{ Ammoniated straw } & \multirow[b]{3}{*}{ SE } \\
\hline & \multicolumn{3}{|c|}{ Supplement ${ }^{a}$} & \multicolumn{3}{|c|}{ Supplement } & \\
\hline & SBM & $\mathbf{B M}$ & $\mathrm{BM}-\mathrm{U}$ & SBM & $\mathbf{B M}$ & BM-U & \\
\hline $\begin{array}{l}\text { ADG } \mathrm{bc}, \mathrm{kg} / \mathrm{d} \\
\text { Feed intakeb, kg/d } \\
\text { Gain/feed bcd }\end{array}$ & $\begin{array}{l}.32 \\
4.70 \\
.069\end{array}$ & $\begin{array}{l}.15 \\
3.93 \\
.039\end{array}$ & $\begin{array}{c}.30 \\
4.22 \\
.069\end{array}$ & $\begin{array}{c}.47 \\
4.72 \\
.100\end{array}$ & $\begin{array}{c}.36 \\
4.83 \\
.073\end{array}$ & $\begin{array}{l}.31 \\
4.78 \\
.066\end{array}$ & $\begin{array}{l}.039 \\
.244 \\
.006\end{array}$ \\
\hline
\end{tabular}

improved gain and DMI of steers fed untreated or ammoniated corn cobs with $.91 \mathrm{~kg}$ alfalfa fed/head, even though adequate (based on the assumption used in supplement formulation for the current studies) levels of a blood mealcorn gluten meal mixture were fed. Further, Teather et al. (1980) noted soybean meal supplementation of corn silage plus concentrate supported a ruminal bacteria population $70 \%$ greater than diets supplemented with urea in lactating dairy cows. Additionally, the bacterial species that require, or are stimulated by, branched-chain volatile fatty acids showed the greatest increases in numbers, probably due to amino acid deamination to volatile fatty acids rather than to direct incorporation into microbial protein. Alfalfa protein, untreated, is similar in degradability in the rumen to soybean meal (Krause and Klopfenstein, 1972), which is 60 to $80 \%$ ruminally degraded (Hume, 1974; Kropp et al., 1976; Merchen et al., 1979; Peterson, 1981), while blood meal is essentially indigestible in the rumen (Stock, 1982).

Supplement formulation was based on data of Stock et al. (1981), which indicated that steers fed a corn silage-corncob diet gained as fast when fed one-half as much $\mathrm{N}$ from blood meal or corn gluten meal, in combination with urea, as soybean meal. This appears to be supported with the untreated wheat straw diets where the soybean meal- and blood meal-ureafed steers had similar gains and gain/feed. The steers fed the untreated wheat straw supplemented with blood meal may have been limited in rumen ammonia due to the low degradability of the blood meal, wheat straw and corn protein in the rumen. However, when the straw was ammoniated, the soybean meal-fed steers appeared to gain faster with similar feed intakes than did the blood meal- or blood meal-urea-fed steers, which performed similarly. Thus, a significant ammonia $\times$ supplement interaction of gain/feed was observed. Similarly, inclusion of a blood meal-corn gluten meal mixture improved $\mathrm{N}$ retention in wethers (Nelson et al., 1984) and bacterial-N flow in steers (Nelson et al., 1982) fed ammoniated corncobs.

It appears then that the first limiting nutrient differed between diets. In the untreated straw diets, energy was first limiting with soybean meal and blood meal-urea supplements, but rumen ammonia was first limiting in the blood meal-supplemented diet. Energy availability was increased by ammonia treatment and the residual ammonia was sufficient to meet rumen ammonia needs. In the blood meal- and blood meal-urea-supplemented diets, rumendegradable protein supplied by the soybean meal probably supplied peptides, amino acids or branched-chain fatty acids for microbial growth because ammonia should have been in excess. This would be in agreement with Brandt et al. (1984), who found a response to rumen degradable proteins with ammoniated corncobs. In trial 1 , alfalfa probably supplied sufficient rumen degradable protein so that the digestible energy content of the diet was the first limiting nutrient.

\section{Literature Cited}

Abidin, A. and T. J. Kempton. 1981. Effects of treatment of barley straw with anhydrous ammonia and supplementation with heat-treated protein meals on feed intake and liveweight performance of growing lambs. Anim. Feed Sci. Technol. 6:145. 
Borhami, B.E.A. and F. Johnsen. 1981. Digestion and duodenal flow of ammonia-treated straw, and sodium hydroxide-treated straw supplemented with urea, soybean meal or fish viscera silage. Acta Agr. Scand. 31:245.

Brandt, R. T. and T. J. Klopfenstein. 1984. Effects of alfalfa plant fractions on intake, digestion and rumen parameters of sheep fed ammoniated corn cobs. J. Anim. Sci. 59(Suppl. 1): 297.

Cook, F. 1981. Hydroxide treatment of corn crop residues. M. S. Thesis. Univ. of Nebraska, Lincoln.

Faulkner, D. B. 1980. The use of wheat straw and corn plant residues in beef production systems. M. S. Thesis. Univ. of Nebraska, Lincoln.

Garrett, W. N., H. G. Walker, G. O. Kohler, A. C. Waiss, R. P. Graham, N. E. East and M. R. Hart. 1974. Nutritive value of $\mathrm{NaOH}$ and $\mathrm{NH}_{3}$ treated rice straw. Proc. West. Sec. Amer. Soc. Anim. Sci. $25: 317$.

Hershberger, T. V., O. G. Bentley and A. L. Moxon. 1959. Availability of the nitrogen in some ammoniated products to bovine rumen microorganisms. J. Anim. Sci. 18:663.

Horton, G.M.J. 1979. Feeding value of rations containing non-protein nitrogen or natural protein and ammoniated straw for beef cattle. J. Anim. Sci. $48: 38$

Horton, G.M.J. and G. M. Steach. 1979. Effect of anhydrous ammonia treatment on the intake and digestibility of cereal straws by steers. J. Anim. Sci. 48:1239.

Hume, I. D. 1974. The proportion of dietary protein escaping degradation in the rumen of sheep fed on various protein concentrates. Australian J. Agr. Res. 25:155.

Kowalczyk, J. 1977. Maximizing NPN use in feeding system based on Agro-Industrial byproducts. In: New Feed Resources. Food and Agriculture Organization, United Nations, Rome.

Krause, V. and T. J. Klopfenstein. 1972. High protein dehydrated alfalfa as a protein source. J. Anim. Sci. 35:269 (Abstr.).

Kropp, J. R., R. R. Johnson and F. N. Owens. 1976. Microbial protein synthesis from urea and soybean meal. J. Anim. Sci. 43:327.

Maeng, W. J. and R. L. Baldwin. 1976. Factors influencing rumen microbial growth rates and yields: Effect of amino acid additions to a purified diet with nitrogen from urea. J. Dairy Sci. 59:648.

Maeng, W., D. Mowat and W. Bilanski. 1970. Digestibility of sodium hydroxide-treated straw fed alone or in combination with alfalfa silage. Can. J. Anim. Sci. 51:743.
McCall, R. and W. R, Graham. 1953. The value of several ammoniated products as feed for beef cattle. J. Anim. Sci. 12:798.

Merchen, N., T. Hanson and T. Klopfenstein. 1979. Ruminal bypass of brewers dried grains proteins. J. Anim. Sci. 49:192.

Millar, H. C. 1944. Ammoniated sugar beet pulp as a new nitrogenous feed for ruminants. J. Dairy Sci. 27: 225.

Nelson, M. L., T. J. Klopfenstein and R. A. Britton. 1984. Protein supplementation of ammoniated roughages. I. Corn cobs supplemented with a blood meal-corn gluten meal mixture-lamb studies. J. Anim. Sci. 59:1601.

Nelson, M. L., T. J. Klopfenstein, R. A. Britton and S. R. Lowry. 1982. Ammoniation and protein supplementation of corncobs. J. Anim. Sci. 55:447 (Abstr.).

Oji, U. I., D. N. Mowat and J. E. Winch. 1977. Alkali treatment of corn stover to increase nutritive value. J. Anim. Sci. 44: 798 .

Paterson, J. A., T. J. Klopfenstein and R. A. Britton. 1981. Ammonia treatment of corn plant residues: Digestibilities and growth rates. J. Anim. Sci. $53: 1592$.

Paterson, J. A., T. J. Klopfenstein and R. A. Britton. 1982. Digestibility of sodium hydroxide-treated crop residues when fed with alfalfa hay. J. Anim. Sci. 54: 1056

Peterson, M. K. 1981. Utilization of supplemental bypass protein in supplements containing blood meal fed to gestating and growing cattle maintained on mature winter range. Ph.D. Dissertation. Univ. of Nebraska, Lincoln.

Snedecor, G. W. and W. G. Cochran. 1967. Statistical Methods (6th Ed.). The lowa State Univ. Press, Ames.

Solaiman, S. G., G. W. Horn and F. N. Owens. 1978. Ammonium hydroxide treatment of wheat straw. J. Anim. Sci. 49:802.

Stock, R. A. 1982. Basic Protein metabolism in ruminants. Ph.D. Dissertation. Univ. of Nebraska, Lincoln.

Stock, R., N. Merchen, T. Klopfenstein and M. Poos. 1981. Feeding value of slowly degraded proteins. J. Anim. Sci. 53:1109.

Teather, R. M., J. D. Erfley, R. J. Boila and F. D. Sauer. 1980. Effect of dietary nitrogen on the rumen microbial population in lactating dairy cattle. J. Appl. Bacteriol. 49:231.

Zinn, R. A., L. S. Ball and R. W. Hemken. 1981. Degradation of supplemental proteins in the rumen. J. Anim. Sci. 52:857. 